\title{
Pemanfaatan Pembobotan Kriteria Dalam Metode AHP Untuk Memprediksi Infeksi Covid-19 Dengan Algoritma Nearest Neighbor
}

\author{
Efori Bu'ulolo ${ }^{1}$, Rian Syahputra ${ }^{2}$ \\ Email: buuloloefori21@gmail.com ${ }^{1}$, ryansyah93@gmail.com² \\ Program Studi Teknik Informatika ${ }^{1}$, Program Studi Sistem Informasi Universitas Budi Darma ${ }^{2}$
}

\begin{abstract}
Abstrak
Covid-19 merupakan salah satu penyakit yang menyerang sistem pernapasan manusia dan pada saat ini pandemi Covid-19 sudah menjadi pandemi global dan sudah memberikan efek yang buruk terhadap kehidupan manusia terutama pada bidang kesehatan dan ekonomi. Infeksi Covid-19 menimbulkan efek paranoid pada masyarakat sehingga menimbulkan ketidaknyamanan dan khawatir tentang lingkungannya. Data-data yang berkaitan Covid-19 sudah banyak terkumpul hanya saja belum banyak dimanfaatkan salah satunya dalam prediksi infeksi Covid-19 terhadap seseorang. Oleh karena itu, sangat diperlukan suatu metode dan algoritma untuk prediksi infeksi Covid-19 berdasarkan gejala-gejala yang dihadapi. Dalam data mining salah satu algoritma yang dapat digunakan untuk memprediksi adalah algoritma nearest neighbor. Algoritma nearest neighbor dapat memprediksi penyelesaian kasus baru / data baru berdasarkan kasus lama / data historis dengan menggunakan pendekatan kriteria dan pembobotan. Agar hasilnya lebih akurat dan valid untuk perhitungan pembobotan nilai kriteria menggunakan metode AHP. Dengan algoritma dan metode tersebut diharapkan dapat membantu masyarakat umum dan tenaga kesehatan dalam memprediksi Infeksi Covid-19 sebelum Swab PCT Test untuk mencegah lebih dini penyebaran Covid-19.
\end{abstract}

Kata kunci: Covid-19, Bobot, Kriteria, Metode AHP, Nearest Neighbor

\section{Pendahuluan}

Coronavirus atau Covid-19 merupakan salah satu virus yang menyebabkan penyakit pada manusia dan hewan, dimana virus tersebut menyerang sistem pernapasan manusia[1]. Saat ini Covid-19 sudah menjadi pandemi global dan efeknya sangat luar bagi kehidupan manusia terutama dari segi kesehatan dan ekonomi. Efek negatif Covid19 salah satunya adalah banyaknya korban sakit dan meninggal serta menyebabkan pertumbuhan ekonomi global turun bahkan minus. Munculnya Covid-19 sebagian besar masyarakat panik serta ada kekhawatiran dan ketakutan yang berlebihan sehingga menyebabkan efek paranoid ditengah-tengah masyarakat. Efek paranoid tersebut membuat seseorang merasa curiga dan tidak percaya terhadap lingkungan sekitarnya[2]. Efek paranoid tersebut disebabkan oleh banyak pemberitaan seputar Covid-19 di berbagai media. Akibatnya ada sebagian masyarakat dengan mudah menuduh seseorang terinfeksi Covid-19 hanya karena seseorang tersebut mengalami salah satu gejala-gejala yang berkaitan dengan Covid-19, bahkan terjadi pengucilan sosial terhadap penderita Covid19.

Seseorang yang diduga terinfeksi Covid19 mengalami gejala seperti suhu badan diatas
370 C, batuk kering, dan sesak napas, kehilangan kemampuan indra penciuman dan perasa serta kelelahan[3][4]. Untuk memastikan gejala-gejala tersebut maka dilakukan Rapid Test dan Swab PCR Test. Jika hasil dari Swab PCR Test positif maka dinyatakan positif terinfeksi Covid-19. Swab PCR Test merupakan alat untuk mendeteksi Covid-19 pada tubuh manusia, dan sekarang dipergunakan sebagai salah satu persyaratan jika melakukan perjalanan baik dalam negeri maupun keluar negeri. Pada saat ini banyak orang melakukan Swab PCR Test untuk mengetahui dirinya terinfeksi Covid-19 atau tidak terutama bagi yang mengalami gejalagejala Covid-19. Pemerintah melalui tim Gugus Tugas dan Rumah Sakit mendata semua yang berkaitan dengan Covid-19 seperti jumlah positif dan gejalanya, sembuh, dirawat, meninggal dan lain sebagainya. Data yang berkaitan dengan Covid-19 sudah banyak dan besar hanya saja belum banyak dimanfaatkan, salah satunya dalam memprediksi seseorang terinfeksi positif Covid-19 atau tidak berdasarkan gejala yang dialaminya dan berdasarkan data Covid-19 sebelumnya. Prediksi ini sangat diperlukan untuk membantu masyarakat dan tenaga medis dalam mengklasifikasi / mengelompokkan dan memprediksi seseorang 
terindikasi terinfeksi Covid-19 sebelum dilakukan Swab PCR Test sehingga ada antisipasi awal dalam mencegah penyebaran Covid-19.

Dalam data mining salah satu algoritma yang dapat digunakan untuk memprediksi adalah algoritma nearest neighbor. Algoritma nearest neighbor adalah algoritma dimana penyelesaian kasus baru berdasarkan kasus lama / data sebelumnya berdasarkan nilai kedekatan kriteria dan nilai bobot kriteria[5][6][7]. Pada algoritma nearest neighbor penentuan nilai bobot kriteria tidak menggunakan aturan baku / nilai bebas. Oleh karena itu, agar hasil prediksi lebih akurat maka penentuan nilai bobot kriteria menggunakan metode Analytical Hierarchy Process (AHP)[8][9]. Berdasarkan penelitian yang dilakukan oleh Ayu Cahyani Febrianti dkk dengan judul Pembobotan kriteria sistem pendukung keputusan pemilihan bidang peminatan menggunakan metode analytic hierarchy process (Studi Kasus: Program studi sistem informasi Universitas Telkom) menyimpulkan bahwa metode AHP dapat digunakan dalam penentuan nilai bobot kriteria dengan menggunakan matriks perbandingan pasangan[10]. Berdasarkan penelitian yang dilakukan oleh Muhammad Ali Purba dengan judul Implementasi algoritma nearest neighbor dalam mengukur tingkat kepuasan masyarakat pada pelayanan Samsat Medan Selatan. Penelitian ini membandingkan data kuesioner wajib pajak pada Samsat Medan Selatan dengan 1(satu) orang wajib pajak atas nama "MIL" yang mempunyai tanggapan yang berbeda. Hasilnya adalah berdasarkan kriteria dan nilai bobot kriteria maka wajib pajak atas nama "MIL" merasa puas dengan pelayanan yang diberikan oleh Samsat Medan Selatan[11].

\section{Metode Penelitian}

Adapun langkah-langkah yang dilakukan pada penelitian ini adalah sebagai berikut:

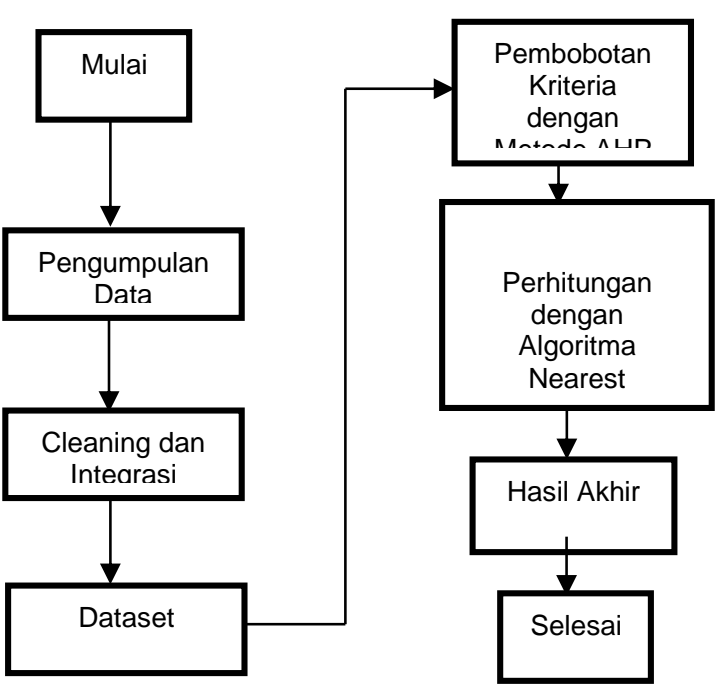

Gambar 1. Metode Penelitian

\section{A. Pengumpulan Data}

Kegiatan paling penting adalah mengumpulkan data. Data yang diambil yaitu data pasien yang melakukan periksa dengan Swab PCR Test beserta gejala yang sedang dialami. Data tersebut diperoleh dari salah satu Rumah Sakit yang ada di Kota Medan. Dari data yang telah ada dilakukan cleaning dan integrasi dan selanjutnya dipilih data secara acak untuk digunakan sebagai dataset.

\section{B. Pembobotan Kriteria}

Langkah selanjutnya adalah melakukan pembobotan kriteria dengan metode AHP. Penting pembobotan kriteria untuk digunakan pada perhitungan algoritma nearest neighbor karena pada algoritma nearest neighbor tidak ada pembobotan kriteria.

\section{Penerapan Algoritma Nearest Neighbor}

Pada penerapan algoritma nearest neighbor data lama atau history pemeriksaan pasien dengan Swab PCR Test dibandingkan satu persatu dengan data baru atau kasus baru berdasarkan kriteria yang telah ada. Nilai yang digunakan adalah nilai bobot kriteria yang diperoleh dengan metode AHP dan nilai kedekatan kriteria. Nilai perhitungan yang paling tinggi yang menjadi hasil akhir.

\section{Hasil dan Pembahasan}

Dalam memprediksi infeksi Covid-19 diperlukan data-data sebelumnya yaitu data yang berkaitan dengan pemeriksaan infeksi Covid-19 terhadap seseorang berdasarkan gejala atau kriteria dan hasil pemeriksaan 
dengan Swab PCR. Data yang telah ada terlebih dahulu dihitung nilai bobot kriterianya dengan menggunakan metode AHP tujuan untuk digunakan pada perhitungan algoritma nearest neighbor dan mengetahui kriteria yang paling berpengaruh terhadap infeksi Covid-19. Berikut adalah data pemeriksaan Covid-19 berdasarkan gejala atau kriteria dan hasil swab PCR yang bersumber dari salah satu Rumah Sakit di Kota Medan.

Tabel 1. Pasien Dengan Hasil Pemeriksaan

\begin{tabular}{|c|c|c|c|c|c|c|c|c|c|}
\hline $\begin{array}{l}\mathrm{N} \\
\mathrm{o}\end{array}$ & $\begin{array}{c}\mathrm{Nam} \\
\mathrm{a}\end{array}$ & $\begin{array}{c}\text { Suh } \\
\text { u } \\
\text { Tub } \\
\text { uh }\end{array}$ & Batuk & $\begin{array}{c}\text { De } \\
\text { ma } \\
\text { m }\end{array}$ & $\begin{array}{c}\text { Hilang } \\
\text { Indra } \\
\text { Penciu } \\
\text { man }\end{array}$ & $\begin{array}{c}\text { Hilang } \\
\text { Indra } \\
\text { Perasa }\end{array}$ & $\begin{array}{c}\text { Kele } \\
\text { laha } \\
n\end{array}$ & $\begin{array}{l}\text { Sesak } \\
\text { Napas }\end{array}$ & $\begin{array}{l}\text { Hasil } \\
\text { Swab } \\
\text { PCR }\end{array}$ \\
\hline 1 & ELS & $\begin{array}{l}> \\
37\end{array}$ & Tidak & $\mathrm{Ya}$ & Ya & Tidak & $\mathrm{Ya}$ & Tidak & Positif \\
\hline 2 & EBU & $<37$ & Tidak & $\mathrm{Ya}$ & Tidak & Tidak & $\mathrm{Ya}$ & Tidak & Negatif \\
\hline 3 & $\mathrm{DV}$ & $>37$ & $\mathrm{Ya}$ & $\mathrm{Ya}$ & Ya & Tidak & $\mathrm{Ya}$ & Ya & Positif \\
\hline 4 & DB & $>37$ & $\mathrm{Ya}$ & Ya & Ya & Tidak & $\mathrm{Ya}$ & Ya & Positif \\
\hline 5 & ER & $>37$ & $\mathrm{Ya}$ & Ya & Ya & Tidak & $\mathrm{Ya}$ & Tidak & Positif \\
\hline 6 & MN & $>37$ & Tidak & $\mathrm{Ya}$ & Tidak & Tidak & $\begin{array}{c}\text { Tida } \\
\mathrm{k}\end{array}$ & Tidak & Negatif \\
\hline 7 & $\overline{\mathrm{EV}}$ & $<37$ & Ya & $\mathrm{Ya}$ & Tidak & Tidak & $\begin{array}{c}\text { Tida } \\
\mathrm{k}\end{array}$ & $\begin{array}{l}\text { Tidak } \\
\end{array}$ & Negatif \\
\hline 8 & $\begin{array}{l}\text { ST } \\
\end{array}$ & $<37$ & Ya & $\mathrm{Ya}$ & Tidak & Tidak & $\begin{array}{c}\text { Tida } \\
\mathrm{k}\end{array}$ & Tidak & Negatif \\
\hline 9 & $\begin{array}{l}\mathrm{KT} \\
\end{array}$ & $>37$ & $\begin{array}{l}\mathrm{Ya} \\
\end{array}$ & $\mathrm{Ya}$ & Ya & Ya & $\mathrm{Ya}$ & $\begin{array}{l}\mathrm{Ya} \\
\end{array}$ & Positif \\
\hline 10 & $\begin{array}{l}\text { FT } \\
\end{array}$ & $<37$ & Tidak & $\begin{array}{c}\mathrm{Ti} \\
\mathrm{da} \\
\mathrm{k}\end{array}$ & Ya & Ya & $\mathrm{Ya}$ & Ya & Positif \\
\hline 11 & NN & $<36$ & Ya & $\begin{array}{c}\mathrm{Ti} \\
\mathrm{da} \\
\mathrm{k}\end{array}$ & $\mathrm{Ya}$ & $\mathrm{Ya}$ & $\mathrm{Ya}$ & Ya & Positif \\
\hline 12 & MY & $>37$ & ya & Ya & Ya & Ya & $\mathrm{Ya}$ & Ya & Positif \\
\hline 13 & SM & $>37$ & $\begin{array}{l}\mathrm{Ya} \\
\end{array}$ & $\mathrm{Ya}$ & Ya & Ya & $\mathrm{Ya}$ & Tidak & Positif \\
\hline 14 & RS & $>37$ & Ya & Ya & Tidak & Tidak & $\mathrm{Ya}$ & Tidak & Negatif \\
\hline 14 & OD & $<36$ & Tidak & $\begin{array}{c}\mathrm{Ti} \\
\mathrm{da} \\
\mathrm{k} \\
\end{array}$ & Tidak & Tidak & $\begin{array}{c}\text { Tida } \\
\mathrm{k}\end{array}$ & Tidak & Negatif \\
\hline 15 & ELS & $<36$ & Tidak & $\mathrm{Ya}$ & Tidak & Tidak & $\mathrm{Ya}$ & Tidak & Negatif \\
\hline 16 & $\mathrm{NL}$ & $<36$ & Tidak & $\begin{array}{c}\mathrm{Ti} \\
\mathrm{da} \\
\mathrm{k}\end{array}$ & Tidak & Tidak & $\mathrm{Ya}$ & Tidak & Negatif \\
\hline 17 & KL & $>37$ & Tidak & Ya & Ya & Tidak & $\mathrm{Ya}$ & Ya & Positif \\
\hline 18 & RK & $<36$ & Tidak & $\begin{array}{c}\mathrm{Ti} \\
\mathrm{da} \\
\mathrm{k} \\
\end{array}$ & Ya & Ya & $\begin{array}{c}\text { Tida } \\
\mathrm{k}\end{array}$ & Tidak & Positif \\
\hline 19 & DD & $>37$ & Ya & $\mathrm{Ya}$ & Ya & Tidak & $\begin{array}{c}\text { Tida } \\
\mathrm{k}\end{array}$ & Tidak & Positif \\
\hline
\end{tabular}

\section{A. Pembobotan Kriteria}

Untuk pembobotan kriteria dalam metode AHP yang dilakukan pertama kali adalah menentukan terlebih dahulu kriteria yang digunakan yaitu sebagai berikut:

Tabel 2. Kriteria Penilaian

\begin{tabular}{cc}
\hline Kode & Nama Kriteria \\
\hline C1 & Suhu Tubuh \\
\hline C2 & Batuk \\
\hline C3 & Demam \\
\hline C4 & Hilang Indra Penciuman \\
\hline C5 & Hilang Indra Perasa \\
\hline C6 & Kelelahan \\
\hline C7 & Sesak Napas \\
\hline
\end{tabular}

Selanjutnya adalah melakukan perbandingan antara kriteria yang satu dengan yang lain dengan menggunakan skala dasar.
Tabel 3. Skala Dasar Perbandingan

\begin{tabular}{cl}
$\begin{array}{c}\text { Intensitas } \\
\text { Kepentingan }\end{array}$ & \multicolumn{1}{c}{ Keterangan } \\
\hline 1 & Sama penting dengan \\
\hline 2 & $\begin{array}{l}\text { Mendekati sedikit lebih } \\
\text { penting dari }\end{array}$ \\
\hline 3 & Sedikit lebih penting dari \\
\hline 4 & Mendekati lebih penting dari \\
\hline 5 & Lebih penting dari \\
\hline 6 & $\begin{array}{l}\text { Mendekati sangat penting } \\
\text { dari }\end{array}$ \\
\hline 7 & Sangat penting dari \\
\hline 8 & Mendekati mutlak dari \\
\hline 9 & Mutlak sangat penting dari \\
\hline
\end{tabular}

Selanjutnya dibentuk matriks perbandingan kriteria dimana nilainya diperoleh dari perbandingan kriteria.

Tabel 4 Matriks Perbandingan Kriteria

\begin{tabular}{cccccccc}
\hline$\#$ & $\mathrm{C} 1$ & $\mathrm{C} 2$ & $\mathrm{C} 3$ & $\mathrm{C} 4$ & $\mathrm{C} 5$ & $\mathrm{C} 6$ & $\mathrm{C} 7$ \\
\hline $\mathrm{C} 1$ & 1 & 0,25 & 2 & $\begin{array}{c}0,1 \\
4\end{array}$ & 3 & $\begin{array}{c}0,3 \\
3\end{array}$ & 0,2 \\
\hline $\mathrm{C} 2$ & 4 & 1 & 4 & 0,2 & 3 & 2 & 0,25 \\
\hline $\mathrm{C} 3$ & 0,5 & 0,25 & 1 & 0,2 & 4 & 2 & 0,5 \\
\hline $\mathrm{C} 4$ & 7 & 5 & 5 & 1 & 5 & 3 & 0,2 \\
\hline $\mathrm{C} 5$ & $\begin{array}{c}0,3 \\
3\end{array}$ & 0,33 & $\begin{array}{c}0,2 \\
5\end{array}$ & 0,2 & 1 & $\begin{array}{c}0,3 \\
33\end{array}$ & 0,2 \\
\hline $\mathrm{C} 6$ & 3 & 0,5 & 0,5 & $\begin{array}{c}0,3 \\
3\end{array}$ & 3 & 1 & 0,33 \\
\hline $\mathrm{C} 7$ & 5 & 4 & 4 & 2 & 5 & 3 & 1 \\
\hline Jlh & $\begin{array}{c}16, \\
83\end{array}$ & $\begin{array}{c}11,3 \\
3\end{array}$ & $\begin{array}{c}16, \\
75\end{array}$ & $\begin{array}{c}4,0 \\
8\end{array}$ & $\begin{array}{c}24, \\
00\end{array}$ & $\begin{array}{c}11, \\
67\end{array}$ & 2,68
\end{tabular}

Selanjutnya adalah perhitungan nilai eigen yang diperoleh dari nilai pada sel dibagi dengan jumlah nilai pada kolom sel tersebut.

Tabel 5. Perhitungan Nilai Eigen

\begin{tabular}{|c|c|c|c|c|c|c|c|c|c|}
\hline $\begin{array}{l}\text { Krite } \\
\text { ria }\end{array}$ & \multicolumn{7}{|c|}{ Nilai Eigen } & Jlh & $\begin{array}{l}\text { Rata- } \\
\text { rata }\end{array}$ \\
\hline $\mathrm{C} 1$ & $\begin{array}{c}0,0 \\
6\end{array}$ & $\begin{array}{c}0,0 \\
2\end{array}$ & $\begin{array}{c}0,1 \\
2\end{array}$ & $\begin{array}{c}0,0 \\
4\end{array}$ & $\begin{array}{c}0,1 \\
3\end{array}$ & 0,03 & $\begin{array}{c}0,0 \\
7\end{array}$ & $\begin{array}{c}0,4 \\
6\end{array}$ & 0,07 \\
\hline $\mathrm{C} 2$ & $\begin{array}{c}0,2 \\
4\end{array}$ & $\begin{array}{c}0,0 \\
9\end{array}$ & $\begin{array}{c}0,2 \\
4\end{array}$ & $\begin{array}{c}0,0 \\
5\end{array}$ & $\begin{array}{c}0,1 \\
3\end{array}$ & 0,17 & $\begin{array}{c}0,0 \\
9\end{array}$ & $\begin{array}{c}1,0 \\
0\end{array}$ & 0,14 \\
\hline C3 & $\begin{array}{c}0,0 \\
3\end{array}$ & $\begin{array}{c}0,0 \\
2\end{array}$ & $\begin{array}{c}0,0 \\
6\end{array}$ & $\begin{array}{c}0,0 \\
5\end{array}$ & $\begin{array}{c}0,1 \\
7\end{array}$ & 0,17 & $\begin{array}{c}0,1 \\
9\end{array}$ & $\begin{array}{c}0,6 \\
8\end{array}$ & 0,10 \\
\hline C4 & $\begin{array}{c}0,4 \\
2\end{array}$ & $\begin{array}{c}0,4 \\
4\end{array}$ & $\begin{array}{c}0,3 \\
0\end{array}$ & $\begin{array}{c}0,2 \\
5\end{array}$ & $\begin{array}{c}0,2 \\
1\end{array}$ & 0,26 & $\begin{array}{c}0,0 \\
7\end{array}$ & $\begin{array}{c}1,9 \\
4\end{array}$ & 0,28 \\
\hline C5 & $\begin{array}{c}0,0 \\
2\end{array}$ & $\begin{array}{c}0,0 \\
3\end{array}$ & $\begin{array}{c}0,0 \\
1\end{array}$ & $\begin{array}{c}0,0 \\
5\end{array}$ & $\begin{array}{c}0,0 \\
4\end{array}$ & 0,03 & $\begin{array}{c}0,0 \\
7\end{array}$ & $\begin{array}{c}0,2 \\
6\end{array}$ & 0,04 \\
\hline C6 & 0,1 & $\begin{array}{c}0,0 \\
4\end{array}$ & 0,0 & $\begin{array}{c}0,0 \\
8\end{array}$ & 0,1 & 0,09 & 0,1 & 0,6 & 0,10 \\
\hline C7 & $\begin{array}{c}0,3 \\
0\end{array}$ & $\begin{array}{c}0,3 \\
5\end{array}$ & $\begin{array}{c}0,2 \\
4\end{array}$ & $\begin{array}{c}0,4 \\
9\end{array}$ & $\begin{array}{c}0,2 \\
1\end{array}$ & 0,26 & $\begin{array}{c}0,3 \\
7\end{array}$ & $\begin{array}{c}2,2 \\
2\end{array}$ & 0,32 \\
\hline
\end{tabular}

Total Rata-rata 1

Perhitungan nilai Eigen yang nilai rataratanya dijadikan sebagai nilai bobot kriteria pada perhitungan algoritma Nearest Neighbor.

Tabel 6. Nilai Bobot Kriteria

\begin{tabular}{llcc}
\hline Kode & Nama Kriteria & $\begin{array}{c}\text { Nilai } \\
\text { Bobot }\end{array}$ & Variabel \\
\hline C1 & Suhu Tubuh & 0,07 & $\mathrm{q}$ \\
\hline C2 & Batuk & 0,14 & $\mathrm{r}$ \\
\hline C3 & Demam & 0,10 & $\mathrm{v}$ \\
\hline C4 & $\begin{array}{l}\text { Hilang } \\
\text { Penciuman }\end{array}$ & 0,28 & $\mathrm{w}$ \\
\hline
\end{tabular}




\begin{tabular}{llll}
\hline C5 & Hilang Indra Perasa & 0,04 & $\mathrm{x}$ \\
\hline C6 & Kelelahan & 0,10 & $\mathrm{y}$ \\
\hline C7 & Sesak Napas & 0,32 & $\mathrm{z}$ \\
\hline
\end{tabular}

Dari Tabel 6. diatas nilai bobot kriteria yang paling tinggi nilainya adalah Sesak Napas (C7) dan Hilang Indra Penciuman (C4) sehingga kriteria tersebut merupakan kriteria paling berpengaruhi terhadap infeksi Covid19.

\section{B. Penerapan Algoritma Nearest Neighbor}

Untuk memprediksi infeksi Covid-19 terhadap seseorang berdasarkan gejala atau kriteria dari data-data sebelumnya dengan algoritma nearest neighbor maka digunakan data sebelumnya yaitu pada Tabel 1. Pasien Dengan Hasil Pemeriksaan. Dalam prediksi infeksi Covid-19 maka diperlukan data pasien dengan gejala atau kriteria tertentu setelah itu dibandingkan satu persatu data tersebut dengan data lama dengan menggunakan nilai bobot kriteria dan nilai bobot perbandingan.

Tabel 7. Data Pasien Terbaru

\begin{tabular}{|c|c|c|c|c|c|c|c|c|c|}
\hline $\begin{array}{l}\mathrm{N} \\
\mathrm{o}\end{array}$ & $\begin{array}{c}\mathrm{Na} \\
\mathrm{m} \\
\mathrm{a} \\
\mathrm{Al} \\
\mathrm{ias}\end{array}$ & $\begin{array}{c}\text { Suh } \\
\text { u } \\
\text { Tub } \\
\text { uh }\end{array}$ & $\begin{array}{l}\mathrm{B} \\
\mathrm{a} \\
\mathrm{t} \\
\mathrm{u} \\
\mathrm{k}\end{array}$ & $\begin{array}{l}\mathrm{D} \\
\mathrm{e} \\
\mathrm{m} \\
\mathrm{a} \\
\mathrm{m}\end{array}$ & $\begin{array}{c}\text { Hilang } \\
\text { Indra } \\
\text { Penciu } \\
\text { man }\end{array}$ & $\begin{array}{l}\text { Hilan } \\
\text { g } \\
\text { Indra } \\
\text { Perasa }\end{array}$ & $\begin{array}{c}\text { Kele } \\
\text { laha } \\
n\end{array}$ & $\begin{array}{c}\text { Ses } \\
\text { ak } \\
\text { Nap } \\
\text { as }\end{array}$ & $\begin{array}{c}\text { Pre } \\
\text { diks } \\
\text { i }\end{array}$ \\
\hline 1 & $\begin{array}{c}\mathrm{Q} \\
\mathrm{LS}\end{array}$ & $\begin{array}{l}> \\
37\end{array}$ & $\begin{array}{l}\mathrm{Y} \\
\mathrm{a}\end{array}$ & $\begin{array}{l}\mathrm{Y} \\
\mathrm{a}\end{array}$ & Ya & Tidak & $\mathrm{Ya}$ & Ya & $?$ \\
\hline 2 & $\begin{array}{l}\mathrm{N} \\
\mathrm{L}\end{array}$ & $>37$ & $\begin{array}{l}\mathrm{Y} \\
\mathrm{a}\end{array}$ & $\begin{array}{l}\mathrm{Y} \\
\mathrm{a}\end{array}$ & Tidak & Tidak & $\mathrm{Ya}$ & $\begin{array}{l}\text { Tid } \\
\text { ak }\end{array}$ & $?$ \\
\hline
\end{tabular}

Selanjutnya membuat tabel untuk mencari nilai kedekatan seperti berikut:

Tabel 8. Nilai Kedekatan Suhu Tubuh

\begin{tabular}{|c|c|c|}
\hline Nilai 1 & Nilai 2 & Nilai Kedekatan \\
\hline$>37$ & $>37$ & 1 \\
\hline$<37$ & $<37$ & 1 \\
\hline$>37$ & $<37$ & 0,5 \\
\hline$<37$ & $>37$ & 0.5 \\
\hline
\end{tabular}

Tabel 9. Nilai Kedekatan Kriteria Lain Selain Suhu Tubuh

\begin{tabular}{|c|c|c|}
\hline Nilai 1 & Nilai 2 & Nilai Kedekatan \\
\hline Ya & Ya & 1 \\
\hline Tidak & Tidak & 1 \\
\hline Ya & Tidak & 0,5 \\
\hline Tidak & Ya & 0.5 \\
\hline
\end{tabular}

Selanjutnya adalah melakukan perhitungan kasus baru dengan kasus lama satu persatu dengan menggunakan rumus nearest neighbor. Perhitungan $=$ Total Dari Nilai Kedekatan Dikali Bobot / Total Bobot Berikut rekapitulasi hasil perhitungan perbandingan kasus baru dengan kasus lama sebagai berikut: Tabel 10. Hasil Perhitungan

\begin{tabular}{|c|c|c|c|}
\hline $\begin{array}{c}\text { No. } \\
\text { Kasus } \\
\text { Baru }\end{array}$ & No.Urut & $\begin{array}{c}\text { Hasil } \\
\text { Perhitungan }\end{array}$ & Keterangan \\
\hline 1 & & 0,82 & \\
\hline
\end{tabular}

\begin{tabular}{|c|c|c|c|}
\hline 1 & & 0,645 & \\
\hline 1 & & 1,05 & $\begin{array}{c}\text { Nilai } \\
\text { Paling } \\
\text { Tinggi }\end{array}$ \\
\hline 1 & & 1,05 & $\begin{array}{c}\text { Nilai } \\
\text { Paling } \\
\text { Tinggi }\end{array}$ \\
\hline 1 & & 0,89 & \\
\hline 1 & & 0,63 & \\
\hline 1 & & 0,68 & \\
\hline 1 & & 0,68 & \\
\hline 1 & & 1,03 & \\
\hline 1 & & 0,875 & \\
\hline 1 & & 0,94 & \\
\hline 1 & & 1,03 & \\
\hline 1 & & 0,87 & \\
\hline 1 & & 0,73 & \\
\hline 1 & & 0,545 & \\
\hline 1 & & 0,645 & \\
\hline 1 & & 0,595 & \\
\hline 1 & & 0,98 & \\
\hline 1 & & 0,665 & \\
\hline 1 & & 0,84 & \\
\hline 2 & 1. & 0,84 & \\
\hline 2 & 2. & 0,945 & \\
\hline 2 & 3. & 0,75 & \\
\hline 2 & 4. & 0,75 & \\
\hline 2 & 5. & 0,91 & \\
\hline 2 & 6. & 0,93 & \\
\hline 2 & 7. & 0,965 & $\begin{array}{c}\text { Nilai } \\
\text { Paling } \\
\text { Tinggi }\end{array}$ \\
\hline 2 & 8. & 0,965 & $\begin{array}{c}\text { Nilai } \\
\text { Paling } \\
\text { Tinggi }\end{array}$ \\
\hline 2 & 9. & 0,73 & \\
\hline 2 & 10. & 0,575 & \\
\hline 2 & 11. & 0,645 & \\
\hline 2 & 12. & 0,73 & \\
\hline 2 & 13. & 0,89 & \\
\hline 2 & 14. & 0,75 & \\
\hline 2 & 15. & 0,845 & \\
\hline 2 & 16. & 0,945 & \\
\hline 2 & 17. & 0,895 & \\
\hline 2 & 18. & 0,68 & \\
\hline 2 & 19. & 0,685 & \\
\hline 2 & 20. & 0,86 & \\
\hline
\end{tabular}

Berdasarkan rekapitulasi pada tabel diatas bahwa hasil perhitungan perbandingan kasus baru no.1 dengan kasus lama, nilai tertinggi terdapat pada no.urut 3 dan 4 pada kasus lama atas nama alias DV dan DB dimana hasil Swab PCR Positif, maka dapat diprediksikan atas nama alias QLS pada kasus baru diprediksikan Positif terinfeksi Covid-19. Begitu juga hasil perhitungan perbandingan kasus baru no.2 dengan kasus lama, nilai 
tertinggi pada nomor urut 7 dan 8 pada kasus lama atas nama alias EV dan ST dimana hasil Swab PCR Negatif, maka dapat diprediksikan atas nama alias NL pada kasus baru diprediksikan Negatif terinfeksi Covid-19.

\section{Kesimpulan}

Kesimpulan dari penelitian ini adalah pembobotan kriteria dengan metode AHP dapat digunakan dalam memprediksi infeksi Covid-19, Nilai bobot kriteria yang diperoleh dengan AHP dapat digunakan dalam memprediksi infeksi Covid-19 dengan algoritma nearest neighbor, Hasil prediksi dapat digunakan sebagai alternatif dalam memprediksi seseorang terinfeksi Covid-19 atau tidak dan juga dapat digunakan sebagai antisipasi awal terhadap penyebaran Covid19.

\section{Daftar Pustaka}

[1] P. K. K. R. dan P. D. P. Indonesia, "Informasi Tentang Virus Corona (Novel Coronavirus)," https://stoppneumonia.id/, 2020. https://stoppneumonia.id/informasitentang-virus-corona-novelcoronavirus/.

[2] dr. R. Fadli, "Kasus Corona dan Berbagai Efek Paranoid yang Muncul," https://www.halodoc.com/, 2020. https://www.halodoc.com/artikel/kasuscorona-dan-berbagai-efek-paranoidyang-muncul.

[3] Https://www.kemkes.go.id/, "Pertanyaan dan Jawaban Terkait COVID-19," https://www.kemkes.go.id/, 2020. https://www.kemkes.go.id/folder/view/f ull-content/structure-faq.html.

[4] S. O. Alam, "8 Tanda-tanda Gejala COVID-19 Terbaru yang Tak Boleh Diabaikan," detik.com, 2021. https://health.detik.com/beritadetikhealth/d-5322856/8-tanda-tandagejala-covid-19-terbaru-yang-tak-bolehdiabaikan/2.

[5] T. Kanungo, D. M. Mount, N. S. Netanyahu, C. D. Piatko, R. Silverman, and $\mathrm{A}$. Y. $\mathrm{Wu}$, "An efficient k-means clustering algorithm: analysis and implementation," IEEE Trans. Pattern Anal. Mach. Intell., vol. 24, no. 7, pp. 881-892, 2002, doi: 10.1109/TPAMI.2002.1017616.

[6] E. Buulolo, "Implementasi Algoritma Apriori Pada Sistem Persediaan Obat ( Studi Kasus: Apotik Rumah Sakit Estomihi Medan )," Pelita Inform. Budi Darma, vol. 4, no. Agustus 2013, pp. 7183, 2013, [Online]. Available: https://www.researchgate.net/publicatio $\mathrm{n} / 312495968$.

[7] E. Buulolo and R. Syahputra, "Implementasi Algoritma Clustering KMeans Untuk Mengelompokkan Mahasiswa Baru Yang Berpotensi ( Studi Kasus : Stmik Budi Darma )," vol. 2, no. September, pp. 17-24, 2019.

[8] E. Darmanto, N. Latifah, and N. Susanti, "Penerapan Metode Ahp (Analythic Hierarchy Process) Untuk Menentukan Kualitas Gula Tumbu," Simetris J. Tek. Mesin, Elektro dan Ilmu Komput., vol. 5, no. $1, \quad$ p. $75, \quad 2014$, doi: 10.24176/simet.v5i1.139.

[9] A. Wibowo and I. Nisaa, "Penentuan Dosen Terbaik Menggunakan Metode Analytical Hierarchy Process (AHP) dan Technique For Order By Similarity To Ideal Solution (TOPSIS): Studi Kasus Akademi Teknologi Bogor," Explor. IT! J. Keilmuan dan Apl. Tek. Inform., vol. 12, no. 2, pp. 62-74, 2020, doi: 10.35891/explorit.v12i2.2288.

[10] A. C. Febryanti, I. Darmawan, and R. Andreswari, "Pembobotan Kriteria Sistem Pendukung Keputusan Pemilihan Bidang Peminatan Menggunakan Metode Analytic Hierarchy Process Studi Kasus: Program Studi Sistem Informasi Universitas Telkom," $J$. Rekayasa Sist. Ind., vol. 3, no. 04, p. 7, 2016, doi: 10.25124/jrsi.v3i04.272.

[11] M. A. Purba, "Implementasi Algoritma Nearest Neighbor Dalam Pelayanan Samsat Medan Selatan," J. Pelita Inform., vol. 18, pp. 551-556, 2019. 